4. Степанова Е.Н., Малярчук В.И., Степанов Н.В. О «презумпции согласия» в правовом регулировании трансплантации органов человека. Вестник РУДН. Медищина. 2002. № 3. С. 17-22.

5. Капитонова Е.А., Романовская О.В., Романовский Г.Б. Правовое регулирование трансплантологии. Монография. М.: Проспект, 2016. 144 c.

6. Алсынбаева Э.М. Правовая природа трансплантационной медицинской помощи. Правовое государство: теория и практика. 2015. № 4. С. 85-90.

DOI https://doi.org/10.30525/978-9934-26-148-0-10

\title{
СХЕМА ОЦІНЮВАЛЬНОГО СИНТЕЗУ ЯК ОСНОВА ДЛЯ ПРАВИЛЬНОГО РОЗУМІННЯ НОРМ ДЛЯ ВИРІШЕННЯ ЄВГЕНА ЕРЛІХА
}

\author{
Савчук В. Г. \\ аспірантка кафедри теорї права та прав людини \\ Чернівецького національного університету імені Юрія Федьковича \\ м. Чернівиі, Україна
}

Євген Ерліх (про нього і його творчість докладно див. [1; 2]) є автором теорії норм для вирішення, яким він присвятив однойменну главу в «Заснуванні соціології права» (1913/1989) [3, с. 111-123]. Ці ж норми він активно використовував в «Юридичній логіці» (1917/18) $[4 ; 5]$, в оригінальному і дуже цікавому предметному покажчику до якої, що міститься тільки в монографічному виданні, наводиться таке визначення-схема цих норм:

«Норми для вирішення:

- Поняття: Норми, згідно з якими суддя вирішує правовий спір ...

- використання яких для побудови правових понять ...

- могло б виводитися із загальних принципів, які запозичуються із правоположень завдяки індукції, для інших, ніж уже вміщених в правоположеннях рішень, виводитися тільки за допомогою повторного зважування інтересів» [5, с. 320].

Норми для вирішення отримали визнання в сучасній філософії $\mathrm{i}$ теорії права, а в також в юридичній методології і теорії юридичної аргументації (Фр. Мюллер, Р. Алексі, Хр. Фішер та ін.). Водночас наведене вище визначення $€$. Ерліха відображає дух часу, в який воно було написано, проте зміни, які відбулися за останні більш, ніж 
100 років, вимагають нового осмислення, яке можна здійснити на основі схеми оцінювального синтезу, запропонованої М. Павчніком на основі піонерських робіт А. Кауфманна. Поєднання норм для вирішення та схеми оцінювального синтезу становить актуальну тему для дослідження, яке має надати одну із відповідей на європейські виклики, які, як вимоги нашого часу, стоять перед юридичною освітою і наукою.

Мета статmi - критичний аналіз відношення норм для вирішення Є. Ерліха і схеми оцінювального синтезу А. Кауфманна/М. Павчніка. Для досягнення цієї мети ми відповімо на такі питання: по-перше, що являє собою схема оцінювального синтезу А. Кауфманна/М. Павчніка; по-друге, як ця схема може бути використана для правильного розуміння норм для вирішення $€$. Ерліха.

1. Схема оцінювального синтезу у роботі М. Павчніка «Юридичне розуміння і вирішування. Від життєвих обставин справи до правового рішення. Внесок до аргументації в праві» (1993) має такий вигляд [6, с. 9]:

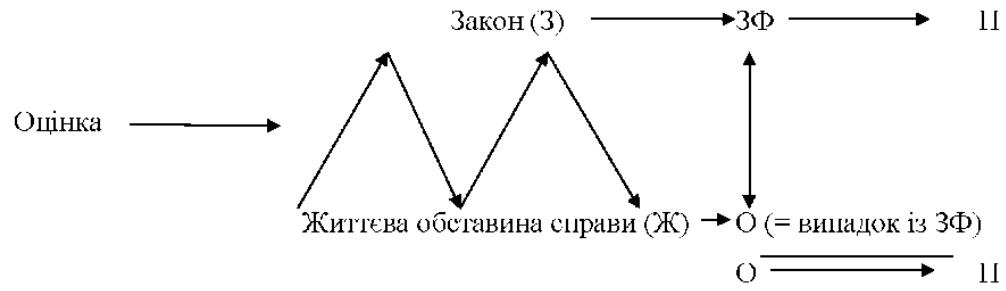

\section{ЗФ означає законний фактичний склад норми, П - правовий наслідок норми, О - обставину справи.}

М. Павчнік пояснює, з посиланням на працю «Аналогія і «природа речі», водночас внесок до вчення про типи» (1965/1982) А. Кауфманна [7], цю схему так: «Правове рішення можливе тільки тоді, коли на основі закону утворюється законний фактичний склад і коли далі із життєвої обставини справи виробляється доконечна (юридично важлива) обставина справа ... . Лише тоді можна встановити, що обставина справи $\epsilon$ випадком законного фактичного складу, до якого прив'язується певний правовий наслідок, який теж мусить конкретизуватися» [6, с. 9], а також: «Життєва обставина справи може юридично дефініюватися як обставина справи тоді, коли вона конструюється тими елементами, які відповідають типовим ознакам законного фактичного складу. Радіус діï законного фактичного складу i життєвої обставини справи, 
iз включеними в них елементами, не може встановлюватися із формально-логічною визначеністю. Таке встановлення було б можливим тільки тоді, коли законний фактичний склад і юридично важлива обставина справи були б зв'язаними один з одним тотожними ознаками. ... Таку «рівність» досягають через встановлення, що юридично важлива обставина справи є випадком законного фактичного складу, що законний фактичний склад і юридично важлива обставина справи однорідні і тому порівнювані.

Отже, і справді йдеться лише про узгодження, а не про рівність, оскільки як нормативний вихідний пункт ..., так і життєва обставина справи за змістом відкриті. Вони не можуть бути цілком співвіднесеними одне з одним. Семантично вони визначаються щораз не тільки із самих себе, а зі свого взаємного зв'язку. Він грунтується на оцінці, яка наповнює семантично відкритий простір (наприклад, що $€$ образою і які конкретні факти конституюють образу). Матеріальна рівність в цьому сенсі є завжди тільки подібністю. Формальна рівність існує тільки в області математичних цифрових даних і знаків. Природа феномена права така, що оцінка грунтується на аналогії, на подібності між юридично важливою обставиною справи і законним фактичним складом. Елементи законного фактичного складу висновуються із елементів життєвих обставин справи, які одні одному тільки подібні. В цьому сенсі також підпорядкування обставини справи під законний фактичний склад може бути лише встановленням того, що елементи юридично важливої обставини справи узгоджуються 3 елементами законного фактичного складу. Лише тоді можна «перекласти» правове рішення в формально-логічні знаки. Лише тоді більший і менший засновок можна залучити до силогічного висновку» [6, с. 10-11].

Викладене вище можна резюмувати наступним чином: існують, з одного боку, закон і життєві обставини справи, а з іншого боку, норми, які утворюються на основі закону і складаються із фактичного складу i правового наслідку, та, власне кажучи, обставини справи, які є описом життєвих обставин справи. Обставини справи і норми узгоджуються у формі оцінювального синтезу, який $\epsilon$ виразом антропного підходу до праворозуміння і полягає в порівнянні або в аналогії, природі речі, типах i tertium comparationis, якщо скористатися термінами А. Кауфманна.

2. Продовжити експлікацію схеми оцінювального синтезу можна якраз в процесі пояснення норм для вирішення Є. Ерліха. Так, Є. Ерліх розуміє норми для вирішення як результат виведення із двох джерел: правоположень, тобто закону в термінології М. Павчніка, а також із правових рішень, які не вміщені в правоположеннях (законах). Отже, в цьому сенсі розуміння $Є$. Ерліха повніше, хоча потрібно відмітити, що 
М. Павчнік поза рамками схеми не заперечує нюанс, відзначений $€$. Ерліхом. Норми для вирішення займають на схемі А. Кауфманна /М. Павчніка правий верхній кут, а тому мають таку структуру: ЗФ $\rightarrow$ П, тобто: якщо має місце такий-то законний фактичний склад, то має місце такий-то правовий наслідок. Проте така схематизація норм для вирішення ще не $\epsilon$ достатньою для їхнього правильного розуміння.

Для такого розуміння потрібно взяти до уваги також поняття «оцінки» як ключового елементу оцінювального синтезу. Є. Ерліх явно чи неявно згадує про неї тоді, коли говорить про зважування інтересів, яке інакше може називатися оцінкою інтересів. Тут ще раз потрібно зауважити, що Є. Ерліх вважав, що «суддя завжди сам мусить знайти норму для вирішення, чи він вирішує без правоположення чи на підставі правоположення; тільки в другому випадку суддівська норма для вирішення визначається вміщеною в правоположенні нормою для вирішення, в першому випадку вона, навпаки, знаходиться цілком вільно» [3, с. 154]. Вільне (і зв'язане) знаходження - це інша форма оцінки. Отже, Є. Ерліх має на увазі універсальну правову оцінку, тобто оцінку, яка відбувається як у формі вільного, так і у формі зв'язаного правознаходження. $\mathrm{B}$ обох випадках правознаходження його результатом якраз і будуть норми для вирішення. Узагальненого можна сказати, що норми для вирішення визначаються завдяки оцінювального синтезу в тій чи іншій формі.

3. Викладене вище дозволяє запропонувати таке визначення норм для вирішення С. Ерліха: норми для вирішення - це утворені на основі позитивного i непозитивного права норми, застосування яких відбувається в результаті оцінки, яка полягає в порівняні, з одного боку, джерел права і життєвих обставини справи та, з іншого боку, власне правових норм і обставин справи, які $\epsilon$ (узгодженим 3 нормою, релевантним) описом життєвих обставин справи.

Висновки. Схема оцінювального синтезу А. Кауфманна/М. Павчніка дозволяє експлікувати і належним, або правильним чином пояснити розуміння Є. Ерліхом норм для вирішення. На іiі основі можна усвідомити дві речі: по-перше, норми для вирішення відрізняються від джерел права як таких, тобто від нормативних актів і джерел неписаного права. По-друге, норми для вирішення $\epsilon$ складовим елементом оцінювального синтезу, який набирає у Є. Ерліха форми зважування інтересів та вільного і зв’язаного правознаходження.

\section{Література:}

1. Rehbinder M. Die Begründung der Rechtssoziologie durch Eugen Ehrlich. 2., völlig neu bearb. Aufl. Berlin: Duncker \& Humblot, 1986. 147 S.: graph. Darst.; Bibliogr. Eugen Ehrlich S. 143-147. 
2. Vogl S. Soziale Gesetzgebungspolitik, freie Rechtsfindung und soziologische Rechtswissenschaft bei Eugen Ehrlich. Baden-Baden: NomosVerl.-Ges., 2003. 396 S.

3. Ehrlich E. Grundlegung der Soziologie des Rechts. 4. Aufl., durchges. u. hrsg. von Manfred Rehbinder. Berlin: Dunker und Humblot, 1989. 441 S.

4. Ehrlich E. Die juristische Logik // Archiv für die civilistische Praxis. 1917. № 115. S. 125-439.

5. Ehrlich E. Die juristische Logik. Tübingen: Mohr, 1918. VII, 337 S.

6. Pavčnik M. Juristisches Verstehen und Entscheiden: vom Lebenssachverhalt zur Rechtsentscheidung; ein Beitrag zur Argumentation im Recht. Wien: Springer, 1993. X, 182 S.

7. Kaufmann A. Analogie und «Natur der Sache», zugleich ein Beitrag zur Lehre vom Typus. 2. Aufl. Heidelberg Hamburg: v. Decker, 1982. XIII, 88 S.

DOI https://doi.org/10.30525/978-9934-26-148-0-11

\title{
ЧУМАЦТВО ЯК ЗАСІБ ПЕРВІСНОГО НАГРОМАДЖЕННЯ КАПІТАЛУ В УКРАЇНІ
}

\author{
Сокур Ю. В. \\ кандидат юридичних наук, дочент, \\ доцент кафедри історії держави та права \\ Національної академії внутрішніх справ \\ м. Київ, Украӥна
}

Торгівля - найдавніша сфера людської діяльності, яка виникла одночасно із виробленням матеріальних благ. Все, що створюється руками людини, призначене або для задоволення власних потреб (натуральне виробництво), або, - 3 виникненням товарного господарства, - для обміну чи продажу іншому споживачеві.

Від давніх давен торговельна діяльність була надзвичайно поширена і на українських землях. Цьому сприяло, зокрема, вдале географічне розташування країни - на перетині цивілізацій і комунікаційних шляхів між північчю й півднем, між сходом і заходом [1].

Торгівля і транспорт в усі часи і понині була обов'язковою передумовою повноцінного функціонування економіки. Торгівля неможлива без транспортування товарів від виробника до споживача. Цю функціональну роль виконувало чумацтво як унікальне явище, притаманне саме Україні. 